\title{
On Objectivity and Actualism in Archaeology
}

\author{
Mats P. Malmer
}

\begin{abstract}
In archaeology objectivity is both possible and necessary. Objectivity primarily means that we at least try to find the truth about what happened in prehistory. A minor fact is worth more than a great fiction. Archaeological actualism has three main variants: ethnoarchaeology, archaeological experiments, and our own personal, subjective impressions of the archaeological material compared with basic physical phenomena in the world around us. Personal actualistic explanations are acceptable and useful if they concern general human conditions.
\end{abstract}

Mats P. Malmer, Department of Archaeology, Stockholm University, SE-106 91 Stockholm, Sweden.

Jacques Lacan somewhere said that a problem which each civilization must consider and try to solve, is how the dead can speak to the living and the living to the dead (cf. Gustafsson 1996:44). I think these words express the meaning and function of archaeology very well. Presumably Lacan did not have prehistoric times particularly in mind, but rather times with a written language. However, the quotation applies very well to archaeology, since it is unique among the humanities in that we have to give prehistoric times a language before a discourse is possible. Or, more exactly, we have to give prehistory a clear-cut language.

Clearness, objectivity and a critical attitude distinguished good historians of all periods. Thukydides writes thus: "But as to the facts of the occurences of the war, I have thought it my duty to give them, not as ascertained from any chance informant nor as seemed to me probable, but only after investigating with the greatest possible accuracy each detail, in the case both of the events in which I myself participated and of those regarding which I got my information from others. And the endeavour to ascertain these facts was a laborious task, because those who were eyewitnesses of the several events did not give the same reports about the same things, but reports varying according to their championship of one side or the other, or according to their recollection." (Book I:22).

Leopold von Ranke, the founder of modern historical research, has a similar position in his field as C. J. Thomsen in archaeology. They were almost the same age (born 1795 and 1788 , respectively), and both carried on traditions from the Enlightenment. In the preface of Ranke's first book are the famous words: "History has assigned to it the task of judging the past, of instructing the present for the benefit of the ages to come. To such lofty functions this work does not aspire. Its aim is merely to show how things actually were", wie es eigentlich gewesen (Ranke 1824, translation by Tosh 1984:11). Ranke demanded of historians that they should use primary and contemporaneous sources, and that they should scrutinize them critically and objectively. Thomsen made exactly the same demands (Malmer 1989). But moreover, Ranke says, the prerequisites of every time must be understood, and its atmosphere and 
mentality has to be reconstructed. We must try to understand why people of the distant past acted as they did. This may be called a hermeneutic outlook.

Obviously it is good to try to understand the situation of people of the past. It gives our own problems more reasonable proportions. To be able to illustrate the long row of past centuries with clear pictures and tales will give most people a feeling of being secure and at home.

Archaeology is useful to the present society, above all owing to its long axis of time, which other humanities lack. Sometimes it is said that archaeology's field of research is only society in its entirety, whereas history often deals with individuals. But it is not quite like that. With the osteologist's help we can draw conclusions from graves, such as age and sex of the deceased, illnesses and possibly the cause of death. Grave-gifts can tell us about ideology, status and wealth. In fact we often know more about an anonymous prehistoric individual than about a medieval person, about whom the written sources often tell nothing more than his name.

The research findings of archaeology are generally reliable, for our sources are numerous and moreover almost always both genuine and truthful. This is not always the case for instance in medieval history, where an important event may be mentioned only in a single text, which furthermore may be tendentious or even faked.

Now, which are prehistoric archaeology's sources of knowledge? Obviously the artefact material. And by artefacts I mean, now and later in this paper, all that is manufactured or worked by man, prehistoric objects and monuments, ecofacts and all traces of man in his environment.

Hardly anybody has failed to notice that during the last few decades the study of artefacts has often been criticized. In many cases the criticism is not rational, but a disinclination for the study of artefact materials is rather shown. A jargon has been develo- ped, in which one condescendingly speaks about a fixation for objects, as if it would be a mistake to examine and document the artefacts carefully. One speaks as if knowledge about prehistoric times could and should be searched for elsewhere than in the artefacts. But if this is considered, it is of course an illusion. All information about prehistoric times is exclusively in the form, substance and location of artefacts. Of course we want knowledge about a prehistoric world of ideas, about social systems, ideology and a lot else that is immaterial. But still the only source of information is nevertheless material: the artefacts' form, substance and location. Sometimes our problem is such that it will not be meaningful to measure the object or study its form in detail. The best strategy is often to see the object in broad outline, to catch its aesthetic qualities. But such an aesthetic impression is also entirely dependent on the object's real, physical form.

My very first archaeological excavation made an ineffaceable impression on me. In November 1945 Professor Greta Arwidsson excavated an Iron Age house near the Jägersro race-course in Malmö, and I was her assistant. It rained, and it was cold and dark. The clay was stiff, and we found very little, just a few undecorated pottery sherds. In those days there was a famous jockey on the racecourse, whose name was George Killick. Not only was he a skilful horseman but also a clairvoyant, a spiritualistic medium. He visited our excavation, and he quickly seized a pot sherd and put it to his forehead. Then he told us what he saw: how the house was furnished during the Iron Age, how fire blazed in the hearth, how men fought and women lamented. I shall not go into my own views about parapsychology, but the comparison between Killick's seance and our method was instructive.

Probably most archaeologists think that a careful record of the details of the artefact material is important. Nevertheless warnings are given against collecting a lot of data 
which will not result in increased knowledge about prehistoric times (Johansen 1979:129). I think that these warnings are unjustified and detrimental. No matter how carefully an artefact material has been studied, it is always possible to make an additional observation. Of course every observation is not equally informative, but any new observation will increase our knowledge about prehistoric times. However, obviously we need a theory to help us find those elements in the artefact material which will give the best possible knowledge.

The word theory has enjoyed changing popularity in the course of time. In the beginning of the 1980s I once found the words "theory" and "theoretical" 16 times in the first half page of a paper by a distinguished colleague. By that time "theory" obviously was a very fashionable word, used to embellish one's text. On the other hand I looked in vain for the word in my own doctoral thesis (Malmer 1962:V and 879). In the latest archaeological texts the word 'theory' is no longer very popular; it has been superseded by other fashionable words. For my part I used "method" and "hypothesis" instead of "theory", because I was of the opinion that these words had a clear meaning, and clearness was something I really aimed at. "Theory", however, is not a sharply defined notion. Prawitz (1995:173) explains the meaning of the word thus: "A group of assumptions or statements which explains phenomena of some kind, and systematizes our knowledge of them". So according to this definition, theory is simply synonymous with sensible mental activity. Thus the difference between theoretical and practical archaeology is small. For example, it is quite correct to say that the planning of an excavation is a theoretical act (Apel et al. 1995:52). Sometimes it is put forward as something rather radical to have a theoretical base when selecting the material details which you intend to discuss, but that is of course self-evident.

In order to function as a good tool arch- aeological theory has to be structured, of course. Trigger (1989:20) has made a classification in three levels. On the lowest level are the data of the artefact material, as well as generalizations of them, usually in the form of defined types. Middle level theory includes generalizations of human behaviour, such as the economic, social and ideological function of artefacts, but also for instance the organization of the family, the structure of the village and political circumstances. Binford's (1981) middle range theory aims at the relation between observable artefacts and archaeologically unobservable human behaviour. And this is, of course, a central point in archaeology.

In the case of high level theory it is necessary to make a more definite choice between systems such as ecological determinism, Marxism and idealism. Trigger points out that these high level theories cannot be tested effectively; rather, they are like religious dogmas. Nevertheless many archaeologists are mostly interested in these high level theories. And nowadays, unfortunately, many think that work on the lowest level is at best uninteresting and at worst meaningless.

Archaeology has two great groups of neighbouring sciences, namely the other humanistic disciplines and the natural sciences. The materials of the first group are verbal and human. The materials of the second group are mute and non-human. The material of prehistoric archaeology is different from that of all these disciplines in that it is both mute and human (Malmer 1984:266, 1993:146). Consequently archaeology is almost unique. Only somatic medicine may be said to have a similar position; and the comparison between archaeology and medicine is not so pointless as it may seem at first. The medicine of the old ages was, at best, common sense, and the same may be said about archaeology before Thomsen.

During the last few decades criticism has often been directed against a supposed ideal 
of natural scientific reasoning, which has been said to characterize archaeology especially during the first half of the 20th century. Possibly archaeological problems have sometimes been treated in such a manner that humanistic aspects are superseded by natural scientific ones, but in my experience, this has not occurred often. The opposite situation is much more frequent. Archaeological artefacts are $100 \%$ substance, even if they express psychological or ideological realities. Thus we cannot, with retained scientific reputation, analyse archaeological materials without mathematical, physical, chemical and other natural scientific methods.

Yet archaeology is not a natural but a humanistic science. The difference is obvious if one tries to use Thomas Kuhn's notion of paradigm in archaeology (Sterud 1973). Kuhn (1970:11) introduces this notion by quoting an example from the history of physical optics. According to Newton's Opticks, which was published in 1703, light consists of small particles. Einstein taught that light is transversal wave motion. Today physics textbooks tell that light is photons, i.e., quantum-mechanical entities. There is no possibility to combine these three explanations into a unitary theory; you have to explain the character of light in one of these three ways. This is the reason why the three theories replaced each other in a revolutionary manner, as the title of Kuhn's book suggests. Common to the three theories is, however, that they are abstract. They have nothing to do with a seeing man's experience of light, and so far they are inconceivable to human common sense.

Incommensurable explanations of this type, which replace each other in a revolutionary manner, cannot exist in archaeology or other behavioural research. Different schools of research certainly exist, but they don't exclude but rather complement each other, and they are, and must be, within the human sphere. Consequently the notion of paradigm does not function well in archaeo- logy.

Of interest is, however, an anecdote about Thomas Kuhn, recently told by his student, Professor John Heilbron (1996). During a cocktail party at Harvard University Kuhn was suddenly asked what type of research he was doing. A silence fell over the room, and everybody listened with strained attention. Then Kuhn answered in real earnest: I seek the truth.

Obviously archaeology should test the applicability of theories and models of explanation in neighbouring sciences, especially anthropology. Ethnoarchaeological research is a very important connecting link between the two disciplines. C. J. Thomsen introduced ethnoarchaeology as early as 1836, and two years later Sven Nilsson published a more detailed version of Thomsen's ideas. Anthropologists of today have largely abandoned ethnographic artefacts, since they are convinced that interviews with living people will give much richer and more clearcut information about society and ideology. And of course they are quite right, provided that one speaks the language of the studied population, and speaks it quite well. It is really not enough to understand the main sense, one must also be able to detect the nuances in a conversation about delicate and important subjects. But in fact it gradually turned out that even prominent anthropologists, such as Margaret Mead, needed help from interpreters. It also appeared that the persons interviewed sometimes told stories which did not really stick to facts, or even tried to make fun of the credulous westerner (Freeman 1989).

Of course it would have been much easier for anthropologists to test the veracity of statements about the functions of artefacts. But of late they have left exactly that undone. So ethnoarchaeology on the whole has been developed only by archaeologists. But in spite of the important work carried out by Binford (e.g. 1967), Hodder (1982) and many others, ethnoarchaeology has not yet acquired the central position that it deserves. Good results 
have been achieved, but most of the work remains to be done.

Archaeologists have a natural disposition to recognize themselves, so to speak, in prehistoric man. They find their own notions and ideas in the artefact material. In the recent literature there are many warnings against this. More seldom are there warnings against a nowadays rather common, opposite inclination to describe prehistoric man as maximally different from people living today.

The founder of modern geology is James Hutton, who was an older contemporary of C. J. Thomsen. In his work Theory of the Earth (1795) he presented a theory which was later called actualism. This theory says that such geological processes which take place in present times happened in the same way in the past, during the historical development of the earth. Consequently the theory can be summarized thus: the present is the key to the past. However, the theory does not rule out that other processes occurred in the past, which have no counterpart in the present.

Obviously the term actualism is of use also in archaeology. One variant of archaeological actualism is ethnoarchaeological methods. Another variant is archaeology by experiment. But the notion of archaeological actualism is much wider. It comprises the totality of modern man's perception of the artefact material compared with the perception of the world around us, not least our everyday surroundings. Surface, weight, light, colour, water, stone and all other such elementary phenomena are probably experienced in the same way by man today as in prehistoric times.

If we want to find Stone Age habitation sites within a certain area we can start by listing those sites which are already known. Then we can make careful statistics of the position of these sites in relation to various elements of the terrain. After that we must revise the numbers with regard to those modern factors which caused the known sites to be discovered. Guided by these data, we can at last try to find new possible places for habitation sites.

But another method is simply to sit down on the hillside and feel whether we are sheltered from the wind and warmed by the sun. And if we feel comfortable on the hillside, it may be worthwhile to dig a test pit. Even if this simple form of actualism is insufficient as the only method to find new habitation sites, it may at least prove helpful.

In most artefact materials there is a polarization into two groups of data. The one group consists of phenomena which can be actualistically interpreted by means of modern ethnographic or western material, or by means of our own personal experience. The other group of data cannot be interpreted in that way. After such a division we shall probably find that part of the actualistically interpreted first group actually seems to have a double explanatory potential, with a link also to the second group. In this way both groups of data will get new explanatory possibilities.

Fig. 1 shows a recently published bronze statuette from the Late Bronze Age, found on the mountain of Kullaberg in north-western Scania (Paulsson 1996). This is the fourteenth statuette known of this type (most of them listed by Malmer 1992:382). Ten of the statuettes have been found in Scania and Zealand, most of them on both sides of the Sound. It has been possible to weigh ten of the statuettes, and six of them have a uniform weight of ca. 107 grams. The other four obviously belong to the same weight system, for one weighs $1 / 2$, one $3 / 4$ and two $5 / 4$ of the standard weight. The Kullaberg statuette weighs almost 106 grams, which means that the weight has once again been confirmed. Further confirmation is provided by the golden so-called oath-rings, which are calibrated according to the same weight system (Malmer 1992:380-383 and Figs. 4-6). It is not unlikely that the basic weight unit of the system is 26.5 grams (Sperber 1996:50), 
which would mean that the weight of the majority of statuettes is equal to four units, whereas one statuette is equal to three units and two are equal to five weight units.

So it seems as well proven as anything in archaeology that the south Scandinavian Bronze Age was acquainted with a weight



Fig. 1. Bronze statuette from Kullaberg, Scania, Sweden. Length $134 \mathrm{~mm}$. Weight $106 \mathrm{~g}$. Photo: Christer Akerberg. system, and used it at least for weighing gold and bronze objects. It is striking that the weight of bronze statuettes was as precisely calibrated as that of the precious gold rings. But a reasonable explanation is that the statuettes were weights and that the gold rings were among such things that were weighed. Weight systems in the Bronze Age of Greece and the Middle East support this hypothesis. For example, it appears that the weight of the Kullaberg statuette corresponds almost exactly to 24 Attic drachmas. And the same weight occurs in Egypt at the time of Akhenaton in the 14th century B.C. (Sperber 1992: 617).

The statuette from Kullaberg and her parallels are so expressive that the explanation may seem quite obvious. Already at the turn of the century Arne (1909:178) wrote that they imitate the goddess Ishtar in Babylonia, who was called Astarte in Phoenicia and Aphrodite on Cyprus. In modern research it would be natural to discuss gender ideas as well. No doubt the statuettes express something about the position of woman in Bronze Age society.

Stenberger (1964:300) adopts Arne's ideas and adds some concrete details: "In their clumsy and modest design they may constitute a cheap mass production, spread among ordinary people. It is close at hand to explain them as images of a goddess, idols, which were placed in the homes and served as a kind of household goddess." On the whole this is pure fantasy, and undoubtedly Stenberger would not have explained the statuettes in this way, if he had known their weight. The first statuette incorporated in the collections of the Stockholm Museum of National Antiquities came from S:t Olof in Scania. This happened in 1895, and you may ask why it took 100 years before the statuettes were weighed. Probably the expressive look of the statuettes was considered to speak for itself. To weigh them would have been a senseless pedantry. But of course the weighing should have been a matter of routine. And if the 
statuettes had been weighed, one would no doubt have soon discovered that they were made in accordance with a strict weight system.

Weighing the statuettes is to use an actualistic method. Metal is expensive today, and it was even more expensive in the early metal age. The peoples of the European continent, who owned the mines, had no reason to send gold and bronze to Scandinavia in unlimited and unweighed quantities. An actualistic explanation of the weights of gold and bronze objects must be that Bronze Age people were scrupulous about these matters.

Of course the appearance of the goddess was by no means insignificant to nordic Bronze Age people, nor were the tales which probably accompanied her from Phoenicia to Scandinavia. On the contrary, the characteristics of the goddess, and the protection she could give, were no doubt important to the Scandinavians. But the accurately calibrated weight could of course not enhance the fame and holiness of the exalted goddess. It would really be absurd if you had to take out a pair of scales to be sure that the statuette represented the right goddess. The weight of the statuette cannot be religiously motivated, but the case must be the opposite: the well-known effigy of the goddess must have legitimated the weight in roughly the same way as the royal hallmark right up to 1972 made the Swedish shopkeepers weights valid. When weights in the Cypriote Bronze Age were shaped like a calf, the signification was the same (Malmer 1992:386). And the dance around the golden calf in Exodus is well known.

The weight of the goddesses is by no means an exception. On the contrary, it is a typical case. No reader of archaeological publications can fail to note that they are often bristling with details, which at first may seem unimportant but which later turn out to be very essential (Malmer 1994). Data no doubt have very different explanatory power, but there are none which are devoid of it.

From the beginning of archaeology the usefulness of chronological data has been regarded as self-evident, but lately it has been debated. Generally speaking, chronology matters less in the modern archaeological literature than in the earlier. Many modern museums no longer display their collections in strict chronological order, and if they do, the exhibition may be criticized as sterile and abstract (Shanks \& Tilley 1987a:68). Surely it is correct to distinguish between a modern, linear perception of time, and an old, cyclic one. In the old peasant society birth, death and the four seasons of the year were noticed, but hardly the numerical sequence of the years (Frykman \& Löfgren 1980:21-44). For my own part this cyclic perception of time is emotionally familiar, and I can actualistically imagine that it was common in prehistoric society. But this does not make chronological ordering less necessary. Even a person with a cyclic perception of time needs a calendar, and a chronology is needed to make a good explanation.

The kind of actualism which I recommend is supported by general theory for the testing of hypotheses. As is well known, Popper (1935) maintains that a scientific thesis must be falsifiable. Many archaeologists, not least in recent times, based their hypotheses on the supposition that prehistoric people had quite different ideas from people living today. No doubt they often did, but hypotheses which are based on that supposition run the risk of being very turgid and imaginative. Above all we almost always lack facts to test them, so few such hypotheses will be falsifiable. We shall have a better logic if instead we assume that prehistoric people were quite like ourselves, well aware that in many respects they certainly were not. In that case we can actualistically contrast our own disposition and our own ideas with the artefacts of the studied period, site or region. With such a method we can, in a number of details, falsify the thesis that the ideas of prehistoric people were like our own. All details, in which the falsifying is successful, constitute the studied 
unit's specific traits. But those details, in which the falsifying is not successful, in all probability constitute universal traits.

Imre Lakatos (1970) to some extent modified Popper's theory about falsifying. He points out that a hypothesis will not be abandoned as soon as it is contradicted by facts and consequently falsified. For hypotheses are not judged isolated, but as parts of a great theoretical system. Such an approach fits archaeological actualism well, since its point is to contrast two great complexes of data, namely the prehistoric artefact material and the world of modern man, including our ethnographic knowledge and our experiments.

Together with social anthropology, archaeology partly developed not only a disregard for artefact material but also for objectivity. The following anecdote could have been fetched from any historical or behavioural discipline: "A few years ago I heard a candidate for a doctoral degree in a social science claim that the demand for objectivity could not possibly be met, and that he for his part intended to ignore it. Instead he meant to start by deciding what conclusions he wished to achieve in his research, his only problem being how to reach them. If such an attitude were to become common our view of science would probably be radically changed" (Bergström 1987:7).

In archaeology several authors spoke about "so-called objectivity", without making the least attempt to explain why, or in what way, an objective archaeological research would not be possible. But also very clear and categorical statements occur: "Theory is thoroughly subjective.... No discourse on the past is neutral.... A unitary and monolithic past is an illusion. What is required is a radical pluralism which recognizes that there are multiple pasts produced actively in accordance with ethnic, cultural and political views, orientations and beliefs" (Shanks \& Tilley $1987 \mathrm{~b}: 212,245$ ). If this is to be literally understood, it is of course an untenable point of view. We investigate a single past, not more. If we observe a certain artefact such as a pottery vessel, it was obviously taken out of the kiln in a definite year, on a definite day and a definite minute. The potter who took it out of the kiln was not a strange compromise between an old man and a young girl. Last week the field was ploughed, or else it was not ploughed. Every detail in the artefact material has such an exact history, and of course Shanks and Tilley are well aware of that. But they are less interested in such details of the prehistoric past which can be absolutely and objectively established. Rather, they wish to tell a subjective story, which may prove effective in current politics.

What do we mean by objectivity? Is objectivity at all possible in archaeology? Yes, it is both possible and necessary. Objectivity means that we at least try to find the truth about what happened in prehistory. In science a minor fact is definitely worth more than a great fiction. Prehistory was not obscure; it consisted of mere distinct events, and these are what we search for in the first place. Secondly, objectivity means that we strive to base our investigation on a representative sample of the infinitely great number of data which the artefact material offers, and to treat these data in a logically faultless way. Thirdly, objectivity means that we do not suppress facts which are contrary to our political ideology or our archaeological hypotheses.

Archaeologists put different questions to the artefact material, because they have different interests and methods, and they judge the answers according to their personal valuations. But is it then really wrong to speak about multiple pasts? Yes, it is. The truth is that there is only one past, not many. Everything happened in one single way, nothing happened in many ways. But isn't this really to catch at words? If everybody is permitted to make a personal evaluation of the research results, could it not with a little poetic licence be allowed to speak about many pasts? No, 
such a formulation must be rejected because it is wrong, and above all dangerous. It will cause, and has already caused, archaeologists to present their picture of the past as if they were writing a novel rather than searching for the truth.

The issue of so-called objectivity, and of choosing a past, originates perhaps mainly in a despair over archaeology's possibilities to reach beyond the trivial and banal and produce a rich and lively picture of prehistoric times. Perhaps it also springs from a reluctance to submit to the laborious work which archaeological artefact material always demanded, and will demand. Of course it is much easier to construct a picture of the past by hand, a picture which with this method can easily be aligned with one's own political ideas. That was how many historians wrote before Ranke, and also after that, before source criticism was generally accepted. On the basis of meagre sources with doubtful veracity, one wrote about one's own country's glorious history, in accordance with one's own political ideas.

If we really fear that archaeology, using a scientifically tenable method, will never produce anything but very simple facts about the prehistoric past, we must still say that it is better to strive for a perhaps never achieved, important and objective truth, than to abandon the demand for truth. But there is really no basis for a pessimistic view on the future of archaeology. The picture of the prehistoric past is continuously more and more concrete, rich and reliable. As a matter of fact archaeology made greater progress than most humanistic disciplines in the post-war period. This of course does not mean that archaeology was theoretically leading; the main reason is archaeology's constantly increasing quantity of artefact material. Many other humanistic and social sciences are now short of early material. For example, within Scandinavian languages the supply of medieval texts has run short, and scholars have turned to the great material of modern texts. Fifty years ago most
Swedish historians worked on problems in medieval history, but now it is difficult to adopt new points of view even on very central events, such as the Kalmar Union beween the Scandinavian countries. For that reason the scholar's interest more and more has turned to modern history, where the material is overwhelmingly extensive. That Scandinavian archaeology made such great advances partly depends on a high interdisciplinary readiness to receive impulses from other subjects. In addition, and above all, archaeology is almost the only humanistic discipline which possesses a really extensive and moreover steadily growing material from the early and earliest ages. No historian believes that a document will suddenly be found which will solve the enigmas of the Kalmar Union. But for every point in prehistory there is a chance that new material will solve already formulated problems, or open quite new possibilities (Malmer 1994:9). Besides, archaeology's existing material is so extensive that by no means has it been examined from all relevant angles. Neighbouring humanistic disciplines seek new research objects, for instance precisely the archaeological artefact material. So it is absurd for archaeologists to despair of the relevance of their own material.

To what extent is actualism consistent with the demand for objectivity? I mentioned three kinds of actualism: ethnoarchaeology, archaeological experiments, and the researcher's personal reaction to the artefact material. The third form of actualism, our personal reaction, is of course subjective in the real sense of the word. In the above the various forms of necessary objectivity have been discussed. What remains is to discuss the different kinds of subjectivism. With reference to Trigger (1989:22) we already stated that high level theories, such as ecological determinism or Marxism, cannot be strictly logically tested. They resemble the dogmas of a religious faith, which may be subjectively accepted or rejected. (But of course high level theories can be judged according to their 
effect on society.) On this level subjectivity is the only possible attitude. But a conscious suppressing of such facts in the artefact material, which are incompatible with one's own general theory, is of course not acceptable.

Also personal actualism exists in different forms. Sensory impressions such as cold and light, or the perception of materials which occurred both in the past and the present, such as water, flint and gold, are easily judged. We experience such phenomena subjectively, but no doubt people of the past experienced them in the same way; or the difference was at least so slight that it may be disregarded. And the list of these kinds of phenomena can be lengthened: food, scents, colours, sounds, weight, swiftness, strength, and hundreds of other experiences. This kind of actualistic subjectivity is obviously no obstacle to the understanding of prehistoric life. On the contrary, this actualism is of course the primary qualification to understand anything of prehistory.

It is more difficult to judge very specific actualistic explanations. As a single example, we can cite a hypothesis that Middle Neolithic megaliths of Västergötland were intended to "create, articulate, and objectify a ritual landscape" (Tilley 1991:76). The roofs of passage graves consist of the same igneous rock (usually diabase) as the flat-topped mountains with steep sides, which dominate the landscape. The upright walls of the megaliths consist of the same sedimentary limestone which forms the bedrock underlying the mountains. "The up-down, high-low contrasts of the landscape are reflected in the very choice of building stones used to construct the tomb". The cup-marks on top of the roofing stones "might represent constellations of stars in the heavens" (1991:74). Of course we cannot exclude the possibility that prehistoric people had very special motives for choosing the form of their monuments; in fact we must assume that they had. But the validity of an actualistic explanation may indeed be questioned if it refers to modern scientific achievements, such as star charts and geological stratification. The possibility of testing the hypothesis is, as always, to confront it with other facts. What proof is there that these very cup-marks were made at the same time as the megaliths? At least the great majority of cup-marks are well dated to the Bronze Age, and consequently more than 1000 years younger than the megaliths. Many other Bronze Age petroglyphs are engraved on Swedish megaliths. Are there any other cup-marks that can be explained as star charts? Furthermore, is it really probable that Middle Neolithic people chose diabase blocks to cover limestone blocks in order to copy the geological stratification? No doubt people at an early stage knew that there is diabase in the mountains and limestone in the fertile plains, but not until the 19th century did anyone imagine that there, remarkably enough, is limestone underneath the diabase mountains. The reason why the roofs of the megaliths are diabase may well be that this kind of rock resists rain and snow very well. Limestone, on the other hand, is full of fissures in which rain-water runs down, and thus there is a great risk that the stone will be splintered by frost. For the walls of the megalith, however, limestone is very suitable since this kind of stone easily splits into flat blocks of a uniform thickness. And the wall blocks are protected against rain by the roof. This alternative actualistic hypothesis is based on the probable assumption that the qualities of rocks were as well known in prehistoric times as they are today.

The difference between the two discussed actualistic hypotheses is obviously the following. The first hypothesis presupposes that prehistoric man had the same, very special, scientific knowledge and conceptions as its author has: star charts and geological stratification. The second hypothesis presupposes only that prehistoric man possessed common sense in a very general branch of knowledge: the quality of rocks in the home district.

However, also rather special phenomena 
and conceptions can be actualistically explained, as shown by the goddess from Kullaberg and her sisters. What is the difference between, on one hand, explaining cup-marks and the selection of rocks in the cited way, and, on the other hand, explaining the statuettes as weights? The second hypothesis is not based on learned speculation but simply on a well-established fact, namely, that man in most and probably in all stages of culture had some measure for economic value, especially when it concerned an imported, rare and useful product. We can draw the conclusion that actualistic explanations in the first place must concern broadly humane conditions. But in certain, and not so rare, cases also very special or individual problems may by solved by means of an actively actualistic attitude.

\section{English revised by Laura Wrang.}

This paper is an abbreviated version of a lecture given on the occasion of the author's 75 th birthday.

\section{ACKNOWLEDGEMENTS}

Thanks to Jenny and Jonas Paulsson for permission to publish Fig. 1.

\section{REFERENCES}

Apel, J. E., et al. 1995. Fågelbacken och trattbägarsamhället. Tor 27. Pp. 47-132.

Bergström, L. 1987. Objektivitet. Stockholm.

Binford, L. 1967. Smudge pits and hide smoking. American Antiquity 32. Pp. 1-12.

- 1981. Bones. Ancient Men and Modern Myths. New York.

Freeman, D. 1989. Fa'apua'a Fa'amu and Margaret Mead. American Anthropologist 91. Pp. 1017-1022.

Frykman, J. \& Löfgren, O. 1980. Den kultiverade människan. Lund.

Gustafsson, L. 1996. Samtal med en stengäst. Bonniers Litterära Magasin. 65/1. Pp. 44-50.

Heilbron, J. 1996. Kan vi lita på vetenskapen? Svenska Dagbladet 28.9.96.

Hodder, J. 1982. Symbols in Action. Cambridge.

Hutton, J. 1795. Theory of the Earth. London.

Johansen, A. B. 1979. Kring prosjektet Norrlands tidiga bebyggelse. Fornvännen. Pp. 126-129.

Kuhn, Th. S. 1970. The Structure of Scientific Revolutions. Chicago.

Lakatos, I. 1970. Falsification and the Methodology of Scientific Research Programmes. In: Lakatos, I. \& Musgrave, A. (Eds). Criticism and the Growth of Knowledge. Cambridge.

Malmer, M. P. 1962. Jungneolithische Studien. Lund.

- 1984. Arkeologisk positivism. Fonuä̈nnen. Pp. 260-268.

- 1989. 'Et mere levende Billede af Fortiden' Mänsklighet genom millennier: En vänbok till Ake Hyenstrand. Pp. 173-179. Stockholm.
- 1992. Weight systems in the Scandinavian Bronze Age. Antiquity 66. Pp. 377-388.

- 1993. On Theoretical Realism in Archaeology. Current Swedish Archaeology, Vol. I. Pp. 145148.

- 1994. Massfyndens egenart och värde. Arkeologiskamassfynd. Riksantikvarieämbetet. Stockholm. Pp. 8-18.

- 1995. Montelius on Types and Find-Combinations. Oscar Montelius 150 years. Vitterhetsakademien. Stockholm. Pp. 15-22.

Nilsson, S. 1838-1843. Skandinaviska Nordens ur-invånare. Ett försök i komparativa ethnografien och ett bidrag till menniskoslägtets utvecklings-historia. Lund.

Paulsson, J. \& J. 1996. Gudinnan på Kullaberg. Kullabygd 69. Pp. 96-100.

Popper, K. 1935. Logik der Forschung. Vienna.

Prawitz, D. 1995. Teori. Nationalencyklopedin, Bd 18. Höganäs.

Ranke, L. von. 1824. Geschichte der romanischen und germanischen Völker 1494-1535. Frankfurt a.d. Oder.

Shanks, M. \& Tilley, C. 1987a. Re-Constructing Archaeology. Cambridge.

- 1987b. Social Theory and Archaeology: Cambridge.

Sperber, E. 1993. Establishing weight systems in Bronze Age Scandinavia. Antiquity 67. Pp. 613-619.

- 1996. Balances, Weights and Weighing in Ancient and Early Medieval Sweden. Stockholm.

Stenberger, M. 1964. Det forntida Sverige. Stock- 
holm.

Sterud, G. 1973. A paradigmatic view of prehistory. In: Renfrew, C. (Ed): The Explanation of Culture Change. London. Pp. 3-17.

Thomsen, C. J. 1836. Ledetraad til Nordisk Oldkyndighed. Copenhagen.

Thucydides. History of the Peloponnesian War.

With an English Translation by Charles Forster
Smith. London 1956.

Tilley, C. 1991. Constructing a Ritual Landscape. Regions and Reflections. In Honour of Märta Strömberg. Lund. Pp. 67-79.

Tosh, J. 1984. The Pursuit of History. London. Trigger, B. 1989. A History of Archaeological Thought. Cambridge. 